\title{
EVALUATION OF LIFE SAFETY TECHNICAL FACILITIES FROM FIRE ON APARTEMENT
}

\author{
Yemima Sahmura $\mathbf{V}^{1 *}$ ) Bangun Indrakusumo Radityo $\mathbf{H}^{2}$ ) \\ *) Corresponding author email : sahmurayemima@gmail.com \\ 1)Planning Development Workshop Architect, Consultant, Jakarta - Indonesia \\ 2) Architecture Departement, Engineering Faculty, Universitas Diponegoro, Semarang - Indonesia
}

\begin{tabular}{l}
\hline Article info \\
MODUL vol 19 no 1, issues period 2019 \\
\hline Doi $\quad: 10.14710 /$ mdl.19.1.2019.50-54 \\
Received $:$ 22nd may 2019 \\
Revised : 23rd may 2019 \\
Accepted $:$ 23rd may 2019
\end{tabular}

\begin{abstract}
Vertical housing of apartments have begun. Housing needs continue to increase as the availability of vacant land is increasingly limited. Occupying an apartment becomes trend and lifestyle for young people. The reason is productivity. The construction of apartments usually built close to various activity centers, both business, commercial, education, health to entertainment. The improvement of building construction is not supported by the land availability especially in the city of Jakarta. Therefore making the construction of high-rise buildings to anticipate it. The construction of multi-story buildings also increases the risk of fire. In 2018, there were at least 1,078 recorded disaster events. Head of the Jakarta Fire and Rescue Management Agency, Subedjo said that 897 buildings or tall buildings in Jakarta, 280 tall buildings had not yet accomplished the fire protection system (Dinas, 2018).

Therefore, this research purpose is to evaluate the lifesaving facilities and infrastructure in the building. The application of fire safety in buildings can be evaluated regarding to NFPA 101 (2013). Based on NFPA 101A: Guide on Alternative Approaches for Life Safety (2013), there are 12 elements of safety and Regulation of the Minister of Public Works No. 26 / PRT / M / 2008 concerning Technical Requirements of Fire Protection Systems in Building Buildings. The building that became the object of research is one of the buildings in the area of Jakarta mentioned building $X$ and building $Y$. The variables that are the focus of the research are fire stairs, fire doors, and access roads.
\end{abstract}

Based on the results of the study, the level of reliability of the means of saving lives against fire hazards in building $X$ is equal to $58 \%$ and in building $Y$ is $65 \%$.

Keywords: means of life-saving; fire protection; evaluation; apartment, Jakarta

\section{INTRODUCTION}

Humans are racing against time, however they also need a place to just rest. Housing needs increased but the availability of land is limited. Occupying an apartment becomes a trend and lifestyle for young people to support productivity. At such ages, their demanded speed and dynamic movement. The housing far distance from the office makes their mobility declining and inefficient. For this reason, the apartment was built to facilitate the movement of its residents. Loft emerged as an interesting dwelling phenomenon in America around the 1950s and developed into a global phenomenon. The form of dwelling that starts from the conversion of industrial buildings to occupancy is considered suitable to answer the challenges of being a flexible, present-day residence. In designing tall buildings, in addition to the architectural aspects of an architect, it is required to admit several other aspects, such as structural, mechanical, electrical and building costs (Juwana, 2005) .With the concept of minimizing human movement, unwittingly, buildings can create new risks that are rarely realized, namely fire (Soewarno, 2015). The fire disaster in Jakarta tended to increase. Based on data from the DKI Jakarta Provincial Fire and Disaster Management Agency in 2013, there were 997 fire incidents. In 2018 there were 951 of which were fire and disaster events due to extreme weather are at least 1,078 disasters. Of these amounts, 692 of them were fire events and 259 disasters due to extreme weather. Fire can be said to be an accident that still often occurs. 
Reflecting on these cases, it is necessary to evaluate the system of life-saving facilities for building fires and continuous improvement. Randomized case studies on 2 buildings in Jakarta as part of efforts to prevent fire accidents by looking at the regulations used, namely NFPA 101A: Guide on Alternative Approaches for Life Safety (2013), with 4 of the 12 main parameters and Regulation of the Minister of Public Works No. 26 / PRT / M / 2008 concerning Technical Requirements for Fire Protection Systems in Building Constructions, focuses on fire stairs, fire doors and exit access roads.

Evaluation that researchers do is using the thought of comparison of rules and case studies in the field so that it can be categorized as semi-quantitative descriptive research. The results of this evaluation indicate that Building $\mathrm{X}$ and Building $\mathrm{Y}$ coincide the standards of Minister of Public Works Regulation No. 26 / PRT / M / 2008 concerning Technical Requirements for Building Fire Protection Systems and NFPA 101A: Guide on Alternative Approaches for Life Safety.

\section{METHOD}

Research by design scheme can be obtained from evaluation based on regulation/literatures, and deeper study about some idea's variables (Harsritanto, 2018).. Literature study, site observation and study cases were fit on evaluation type of studies (Harsritanto et al, 2017 dan Dumanski, 1997). The literature/regulation studies will sharpen the evaluation criteria and value. Site observation to get the real value of the study objects according to the formed evaluation sheets. And last the cases studies will complete the research by heuristic study about the past, present and future conditions related to the evaluation criterias (Harsritanto, 2018).This is the research conducted using a qualitative descriptive method by means of case studies, in which the results of the study are described, analyzed and then drawn conclusions in solving them. This research was carried out on fire stairs, fire doors and exit access parameters used to refer to the Minister of Public Works Regulation No. 26 / PRT / M / 2008 concerning Technical Requirements of Fire Protection Systems in Building Constructions. There are 2 story-buildings as case studies, namely building $\mathrm{X}$ and building $\mathrm{Y}$.

The method used in carrying out observations regarding the evaluation of the life safety system against building fires is:

1. Method of observation

2. Design Plan data

3. Literature study method.

The data analysis technique (SNI, 2015) carried out in writing this research is to compare the data in the field, namely:
1. Fire Ladder

2. Fire door

3. Exit Access

With the provisions contained in the SNI Standard 031736 Year 2000; Technical provisions for saving the life against fire hazards in buildings and the environment; the Decree of the Minister of Public Works No.10 / KPTS / 2000; Regulation of the Minister of Public Works No. 26 / PRT / M2008 dated 30 December 2008 concerning Technical Requirements.

\section{ANALYSIS AND INTERPRETATION}

The Case studies carried out in Building $\mathrm{X}$ and Building $\mathrm{Y}$ are buildings that have a height of $>30$ floors, and function as a place to fulfill human needs in this modern era. They are located in the city center with easy accessibility and in one environment with an advanced economic level (see figure 1 and 2).

The brief conditions of building $\mathrm{X}$ and $\mathrm{Y}$ are :

Building $\mathrm{X}$ is apartment with $\mathrm{L}$ shape and having double core on each end of sides. The core areas were assymetrical and followed the building shape.

Building Y is apartment with I shape and having double core on each end of sides. The core areas were symetrical and followed the building shape.

Both of the apartments were highrise kind of buildings, so the fire protection system as life technical facilities are a must prepared and ready to use devices.

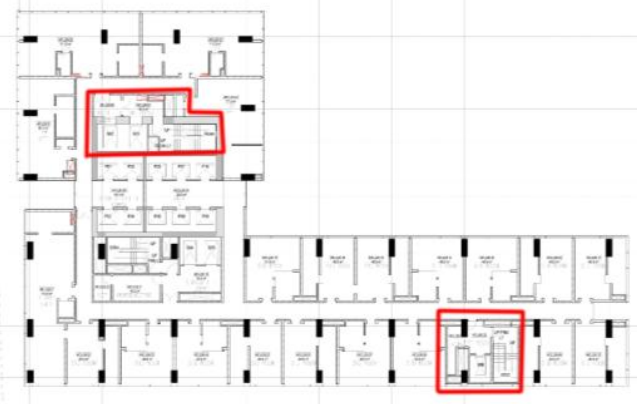

Figure 1. Plan of $18^{\text {th }}$ floor Building $X$

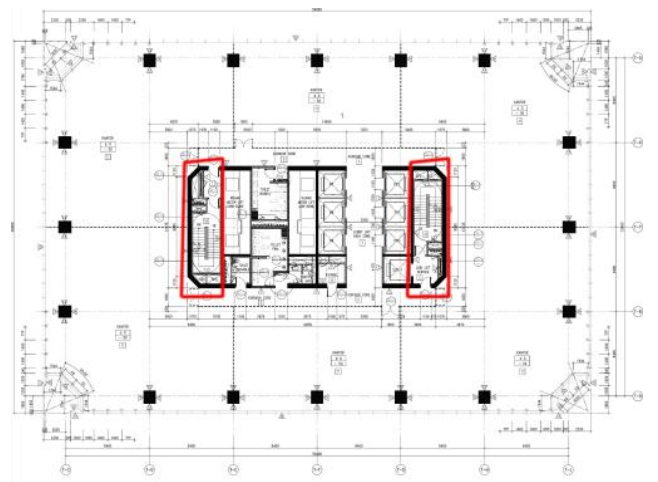

Figure 2. Plan of 18th floor Building Y 
Each building has Design Development Parameter of height, number of floors, refugees and fire shaft, etc as follows on table 1 :

Table 1. Development Parameter Management

\begin{tabular}{|l|l|l|}
\hline & Building X & Building Y \\
\hline Area & $1985 \mathrm{~m} 2$ & $2007 \mathrm{~m} 2$ \\
\hline Height & $168 \mathrm{~m}$ & $188 \mathrm{~m}$ \\
\hline Floors & 42 floor & 47 floor \\
\hline Refugee & 4 Refugee & 4 Refugee \\
\hline Fire Shaft & 2 Fire shaft & 2 Fire Shaft \\
\hline $\begin{array}{l}\text { Type } \\
\text { Building of }\end{array}$ & Apartemen & Office \\
\hline Year of Project & 2017 & 2016 \\
\hline Status & Awakened & Awakened \\
\hline
\end{tabular}

Based on the applicable regulations, the implementation of building security, especially against fire hazards, must be carried out properly. To overcome this, building $\mathrm{X}$ and building $\mathrm{Y}$ are required fire stairs, fire doors and exit access that provide a means of saving lives efficiently inside and outside the building. The evaluation of each emergency stairs can be seen as follows:

1. Wide

2. Foothold

3. Footing height

4. Handrail

5. Material

6. Finishing, and

7. Floor conditions

Table 2. Fire Stair Evaluation; Building $X$

\begin{tabular}{|c|c|c|c|c|}
\hline Parameter & \multicolumn{2}{|l|}{ Standard } & $\begin{array}{l}\text { Study } \\
\text { Results }\end{array}$ & Information \\
\hline \multirow{6}{*}{ Fire stairs } & Wide & $\begin{array}{l}\text { Min. } 120 \\
\mathrm{~cm}\end{array}$ & $120 \mathrm{~cm}$ & fulfilled \\
\hline & Foothold & $\begin{array}{l}\text { Min. } \\
27,9 \mathrm{~cm}\end{array}$ & $28,1 \mathrm{~cm}$ & fulfilled \\
\hline & $\begin{array}{l}\text { Footing } \\
\text { Height }\end{array}$ & $\begin{array}{l}10,2- \\
18 \mathrm{~cm}\end{array}$ & $18,2 \mathrm{~cm}$ & $\begin{array}{l}\text { not } \\
\text { fulfilled }\end{array}$ \\
\hline & $\begin{array}{l}\text { Handrail } \\
\text { Height }\end{array}$ & $\begin{array}{l}90- \\
105\end{array}$ & $100 \mathrm{~cm}$ & fulfilled \\
\hline & Material & Concrete & Concrete & fulfilled \\
\hline & $\begin{array}{l}\text { Finishing } \\
\text { Floor }\end{array}$ & $\begin{array}{l}\text { Not } \\
\text { Slippery }\end{array}$ & $\begin{array}{l}\text { Not } \\
\text { Slippery }\end{array}$ & fulfilled \\
\hline
\end{tabular}

Table 3. Fire Stair Evaluation; Building Y

\begin{tabular}{|c|c|c|c|c|}
\hline Parameter & \multicolumn{2}{|l|}{ Standard } & $\begin{array}{l}\text { Study } \\
\text { Results }\end{array}$ & Information \\
\hline \multirow{6}{*}{ Fire stairs } & Wide & $\begin{array}{l}\text { Min. } 120 \\
\mathrm{~cm}\end{array}$ & $120 \mathrm{~cm}$ & fulfilled \\
\hline & Foothold & $\begin{array}{l}\text { Min. } \\
27,9 \mathrm{~cm}\end{array}$ & $28,1 \mathrm{~cm}$ & fulfilled \\
\hline & $\begin{array}{l}\text { Footing } \\
\text { Height }\end{array}$ & $\begin{array}{l}10,2- \\
18 \mathrm{~cm}\end{array}$ & $19 \mathrm{~cm}$ & $\begin{array}{l}\text { not } \\
\text { fulfilled }\end{array}$ \\
\hline & $\begin{array}{l}\text { Handrail } \\
\text { Height }\end{array}$ & $\begin{array}{l}90- \\
105 \\
\mathrm{~cm}\end{array}$ & $100 \mathrm{~cm}$ & fulfilled \\
\hline & Material & Concrete & Concrete & fulfilled \\
\hline & $\begin{array}{l}\text { Finishing } \\
\text { Floor }\end{array}$ & $\begin{array}{l}\text { Not } \\
\text { Slippery }\end{array}$ & $\begin{array}{l}\text { Not } \\
\text { Slippery }\end{array}$ & fulfilled \\
\hline
\end{tabular}

From the evaluation on the tables 2 and 3 that the fire stairs in building $\mathrm{X}$ and building $\mathrm{Y}$ are found parts that have not fulfilled the requirements, namely the height of the footing. It is not as required so that in an emergency the stairway can be a threat.

In addition to the state of the Fire Ladder in the table above, the next parameter is the Fire Door. This door serves to protect from fire when a fire occurs, so that the humans inside the fire shaft can avoid the incoming fire. The evaluation of each Fire Door can be seen as follows:

Table 4. Fire Door Evaluation; Building X

\begin{tabular}{|l|l|l|l|l|}
\hline Parameter & \multicolumn{2}{|l|}{ Standard } & $\begin{array}{l}\text { Study } \\
\text { Results }\end{array}$ & Parameter \\
\hline \multirow{5}{*}{ Fire Door } & Trusht & $\begin{array}{l}\text { Min. } 67 \\
\mathrm{~N}\end{array}$ & $67 \mathrm{~N}$ & fulfilled \\
& $\begin{array}{l}\text { Height } \\
\text { Panic } \\
\text { Bar } \\
\text { Opening }\end{array}$ & $\begin{array}{l}75 \mathrm{~cm}- \\
110 \mathrm{~cm} \\
\text { from } \\
\text { floor }\end{array}$ & $75 \mathrm{~cm}$ & fulfilled \\
\cline { 2 - 5 } & $\begin{array}{l}\text { Wide } \\
\text { Exit } \\
\text { Direction }\end{array}$ & There & $80 \mathrm{~cm}$ & fulfilled \\
\cline { 2 - 5 } & Material be & Firerated & Firerated & fulfilled \\
\cline { 2 - 5 } & $\begin{array}{l}\text { Finishing } \\
\text { Door }\end{array}$ & Firerated & Firerated & fulfilled \\
\hline
\end{tabular}


Table 5. Fire Door Evaluation; Building Y

\begin{tabular}{|l|l|l|l|l|}
\hline Parameter & \multicolumn{2}{|l|}{ Standard } & $\begin{array}{l}\text { Study } \\
\text { Results }\end{array}$ & Parameter \\
\hline \multirow{5}{*}{ Fire Door } & Trusht & $\begin{array}{l}\text { Min. } 67 \\
\mathrm{~N}\end{array}$ & $67 \mathrm{~N}$ & fulfilled \\
\cline { 2 - 5 } & $\begin{array}{l}\text { Height } \\
\text { Panic } \\
\text { Bar }\end{array}$ & $\begin{array}{l}75 \mathrm{~cm}- \\
110 \mathrm{~cm} \\
\text { from } \\
\text { floor }\end{array}$ & $75 \mathrm{~cm}$ & fulfilled \\
\cline { 2 - 5 } & $\begin{array}{l}\text { Wide } \\
\text { Direction }\end{array}$ & \begin{tabular}{l}
$80 \mathrm{~cm}$ \\
\cline { 2 - 5 }
\end{tabular} & $\begin{array}{l}\text { Exit } \\
\text { Direction }\end{array}$ & There \\
must be & fulfilled & fulfilled \\
\cline { 2 - 5 } & Material & Firerated & Firerated & fulfilled \\
\cline { 2 - 5 } & $\begin{array}{l}\text { Finishing } \\
\text { Door }\end{array}$ & Firerated & Firerated & fulfilled \\
\hline
\end{tabular}

From the evaluation on the tables 4 and 5, the fire door in building $\mathrm{X}$ and building $\mathrm{Y}$ have parts that have met the requirements, which are required so that the conditions are safe.

In addition to the state of the Fire Door in the table above, the next parameter is Exit Access, this door serves to provide instructions and directions that does not make people confused when a fire occurs and can leave the building safely. The evaluation of each Fire Exit Access can be seen as follows:
1. Ceiling height
2. Hidrant box
3. Apar sprinkler
4. Wide Opening corridor
5. Smoke stop lobby
6. Fire resistance level
7. Finishing doors condition

From the evaluation in the table 6 and 7, Some parts of Exit Access in building $\mathrm{X}$ and building $\mathrm{Y}$ do not meet the requirements. The sprinkler is one form of protection against fire hazards in buildings such as water transmitters (Fitzgerald, 2014). The system used must be in the building as required so that building $X$ and building Y have fitted. Wide opening direction are not clearly. They are have $1,1 \mathrm{~m}$ for clearance. Therefore, when a fire occurs, it is very dangerous because the humans inside do not know the right path to get out.
Table 6. Exit Access Evaluation; Building X

\begin{tabular}{|c|c|c|c|c|}
\hline Parameter & \multicolumn{2}{|l|}{ Standard } & Study & Parameter \\
\hline \multirow{6}{*}{$\begin{array}{l}\text { Exit } \\
\text { Access }\end{array}$} & $\begin{array}{l}\text { Celling } \\
\text { Height }\end{array}$ & $\begin{array}{l}\text { Min. } \\
2.25 \mathrm{~m}\end{array}$ & $67 \mathrm{~N}$ & fulfilled \\
\hline & $\begin{array}{l}\text { Hidrant } \\
\text { box, Apar, } \\
\text { Sprinkler }\end{array}$ & $\begin{array}{l}\text { There } \\
\text { must be }\end{array}$ & fulfilled & fulfilled \\
\hline & $\begin{array}{l}\text { Wide } \\
\text { Opening } \\
\text { Corridor }\end{array}$ & $\begin{array}{l}1.20 \mathrm{~m}- \\
1.5 \mathrm{~m}\end{array}$ & $1.10 \mathrm{~m}$ & $\begin{array}{l}\text { Not } \\
\text { fulfilled }\end{array}$ \\
\hline & $\begin{array}{l}\text { Smoke } \\
\text { Stop Lobby }\end{array}$ & $\begin{array}{l}300 \mathrm{~cm} \mathrm{x} \\
200 \mathrm{~cm}\end{array}$ & fulfilled & fulfilled \\
\hline & $\begin{array}{l}\text { Fire } \\
\text { Resistaance } \\
\text { Level }\end{array}$ & 1 Hours & 1 Hours & fulfilled \\
\hline & $\begin{array}{l}\text { Finishing } \\
\text { Door }\end{array}$ & Firerated & Firerated & fulfilled \\
\hline
\end{tabular}

Table 7. Exit Access Evaluation Building Y

\begin{tabular}{|c|c|c|c|c|}
\hline Parameter & \multicolumn{2}{|l|}{ Standard } & Study & Parameter \\
\hline \multirow{6}{*}{$\begin{array}{l}\text { Exit } \\
\text { Access }\end{array}$} & $\begin{array}{l}\text { Celling } \\
\text { Height }\end{array}$ & $\begin{array}{l}\text { Min. } \\
2.25 \mathrm{~m}\end{array}$ & $67 \mathrm{~N}$ & fulfilled \\
\hline & $\begin{array}{l}\text { Hidrant } \\
\text { box, Apar, } \\
\text { Sprinkler }\end{array}$ & $\begin{array}{l}\text { There } \\
\text { must be }\end{array}$ & fulfilled & fulfilled \\
\hline & $\begin{array}{l}\text { Wide } \\
\text { Opening } \\
\text { Corridor }\end{array}$ & $\begin{array}{l}1.20 \mathrm{~m} \mathrm{-} \\
1.5 \mathrm{~m}\end{array}$ & $1.60 \mathrm{~m}$ & $\begin{array}{l}\text { Not } \\
\text { fulfilled }\end{array}$ \\
\hline & $\begin{array}{l}\text { Smoke } \\
\text { Stop Lobby }\end{array}$ & $\begin{array}{l}300 \mathrm{~cm} \mathrm{x} \\
200 \mathrm{~cm}\end{array}$ & fulfilled & fulfilled \\
\hline & $\begin{array}{l}\text { Fire } \\
\text { Resistaance } \\
\text { Level }\end{array}$ & 1 Hours & 1 Hours & fulfilled \\
\hline & $\begin{array}{l}\text { Finishing } \\
\text { Door }\end{array}$ & Firerated & Firerated & fulfilled \\
\hline
\end{tabular}

\section{CONCLUSIONS AND RECOMMENDATIONS}

Based on the results of the research conducted, it can be concluded that the physical condition of the fire stairs in buildings $\mathrm{X}$ and $\mathrm{Y}$ does not meet the requirements, especially the height of the footing. And from the evaluation in the tables above, some parts of Exit Access in building $\mathrm{X}$ and building $\mathrm{Y}$ do not meet the requirements. Wide opening direction are not clearly. They are have $1,1 \mathrm{~m}$ for clearance. Therefore, 
when a fire occurs, it is very dangerous because the humans inside do not know the right path to get out.

But for evaluation in the tables above, some parts of fire doors in building $\mathrm{X}$ and building $\mathrm{Y}$ have met the requirements, which are required so that conditions are safe. Of the 3 that are required, 2 parameters have not fulfilled the requirements and because this research is only limited to the sample that has been mentioned so that in the future the government and the implementers of construction are more concerned and both control intensively, if not, it will be fatal in the future.

\section{REFERENCES}

Dinas Pemadam Kebakaran dan Penanggulangan Bencana (2018) Rekapitulasi Kejadian Kebakaran Bulanan di provinsi DKI Jakarta Tahun 2013

Fitzgerald, R.W. (2014). Building Fire Performace Analysis, USA: Worcester Polytechnic Institute.

Harsritanto, Bangun IR (2018) Urban Environment Development based on Universal Design Principles, E3S Web of Conferences 31, 09010

Harsritanto, Bangun IR (2018) Sustainable Streetscape Design Guideline based on Universal Design Principles, MATEC Web of Conferences 159, 01003

Harsritanto, Bangun IR, et al (2017) Universal design characteristic on themed streets, IOP Conf. Ser.: Earth Environ. Sci. 99012025

Juwana, J.S. (2005). Panduan Sistem Bangunan Tinggi, Jakarta: Erlangga.

Kementrian Pekerjaan Umum. (2008) Peraturan Mentri Pekerjaan Umum Nomor 26 Tahun 2008 tentang Persyaratan Teknis sistem Proteksi Kebakaran pada Bangunan Gedung dan Lingkungan.

Kementrian Pekerjaan Umum. (2000) Ketentuan Teknis Pengamanan Terhadap Bahaya Kebakaran pada Bangunan Gedung dan Lingkungan.

NFPA. (2012) Life Safety Code, Edition 2012, National Fire Protection Association: Worcester Quincy MA.

NFPA. (2013) Guide on Alternative Approaches to Life Safety, Edition 2013, National Fire Protection Association: Worcester Quincy MA.

NFPA. (2013) Standard on Types of Building Construction, Edition 2013, National Fire Protection Association: Worcester Quincy MA.

SNI 03-1746-1989. (2015). Tata Cara Pemasangan Alat bantu Evakuasi Untuk Pencegahan Bahaya Kebakaran Pada Bangunan Rumah dan Gedung, Jakarta: Jakarta.

Soewarno, Soekartono. (2015). Pemahaman Teknis Sarana Evakuasi Pada Bangunan Gedung, Vol. 1, Jakarta: Persatuan Insinyur Indonesia. 